\title{
Impact of Submergence Stress on Growth analytical Parameters of Different Rice Genotypes in Coastal Odisha
}

\author{
Neeva Mohapatra ${ }^{{ }^{*}}$ and B.K. Hota ${ }^{2}$ \\ ${ }^{1}$ K.V.K. Puri, Odisha, India \\ ${ }^{2}$ Department of Plant Physiology, College of Agriculture, OUAT, Bhubaneswar-03, India \\ *Corresponding author
}

\section{A B S T R A C T}

Coastal Odisha is one of the most flood prone areas of India where the paddy crop in the wet season is often devastated by flash floods with an average productivity of only $0.5-0.8$

\section{Keywords}

High Yielding

Varieties (HYVs),

Rice, LAI

Article Info

Accepted:

10 September 2018

Available Online:

10 October 2018 $\mathrm{t} \mathrm{ha}^{-}{ }^{1}$. The present study showed that farmers preferred to cultivate low yielding traditional land races owing to their better flood tolerance and the unavailability of flood tolerant high yielding varieties (HYVs). The main goal of this study is to identify new genetic resources tolerant to submergence based on morpho-physiological traits. Field experiment comprising 22 varieties which were completely submerged for 15 days under RBD design was conducted to screen out the submergence tolerant varieties basing upon morpho-physiological characters in the costal ecosystem of Odisha during kharif 2015 in the Adaptive Research Station, Sakhigopal. Greater genetic variability was observed for different physiological parameters. There was highly positive correlation between LAI, NAR, RGR CGR and LAD with yield and yield attributing characters which are found to be highest in varieties like Sabita, FR-43B and Jalamagna. NAR is positively associated with SLW and negatively with LAR. So all these can be selected as useful parameters for selection of a variety to have higher grain yield.

\section{Introduction}

Rice is a staple food for more than half of the world's 7 billion people. More than $90 \%$ of the global rice is produced and consumed in Asia. South Asia has about 37\% of the world's total rice area and approximately half of that is rainfed (Dawe et al., 2010). Flash floods leading to complete submergence of plants for $10-15$ days are one of the major recurring problems for rice production in rainfed lowlands of South and South- East Asia (Septiningsih et al., 2009). In India 30\% of the rice growing area (12-14 $\mathrm{M}$ ha) is prone to flash flooding with average productivity of only $0.5-0.8 \mathrm{t}$ ha -1 (Bhowmick et al., 2014). Coastal Odisha is one of the most flood prone areas of India where the paddy crop in the wet season is often devastated by flash floods, causing farmers either to discontinue paddy cultivation or revert to low-yielding traditional land- races. Thus, the recurrent floods reduce farmers' seasonal earnings, thereby affecting their inclination to experiment with the latest technologies, including planting new varieties with tolerant mechanism (Dar et al., 2013). 
Submergence tolerance includes a number of anatomical (formation of aerenchyma cell), physiological (shoot elongation with increase in adventitious roots), and biochemical (inhibition of chlorophyll degradation, less utilization of storage carbohydrates) adaptations. Plants respond to submergence at the molecular, cellular and physiological levels which vary among species and genotype, length and severity of submergence, crop age and stage of development, organ and cell type and sub-cellular compartment. Furthermore, physiological basis of yield gap among high yielding rice cultivars has not been studied extensively under coastal ecosystem of Odisha. Such information is vital for identifying the physiological and morphological traits to support the selection and breeding of high yielding rice cultivars. Efforts are few to address the growth, physiological responses and yield of rice to water stress under tropical environment (Zain et al., 2014). Therefore, different physiological parameters have been taken in to consideration and an attempt has been made to assess the influence of submergence on subsequent growth period of crop ontogeny and yield.

\section{Materials and Methods}

\section{Plant culture and growth condition}

The experiment was conducted at the Adaptive Research Station, Sakhigopal, Puri, Orissa, India (19048' N, 85052' E, and 6 m above the mean sea level) to study the effects of submergence on different morphophysiological characteristics and their association with different yield contributing characters, which would guide breeding strategies for tolerance under submergence. The experiment was conducted in sandy clay loam soil ( $\mathrm{pH} 6.4$, organic C $0.68 \%$, total $\mathrm{N}$ $0.01 \%$, available $\mathrm{P} 17.5 \mathrm{~kg} / \mathrm{ha}$, and available $\mathrm{K}$ $129 \mathrm{~kg} / \mathrm{ha}$ ). The nursery bed was developed for planting of 22 paddy varieties namely
Sabita, FR43B, Jalamagna, OR-2331/14, IR 85085 SUB-17 Jayanti Dhana, Jalamani, CR Dhan-500, CR Dhan-401, CR Dhan-505, Mahalaxmi Manika, CR Dhan-1030, OR142/99, Tanmayee, Urbashi, Salibahana, Rambha, OR/2328/05, Mayurakantha, Bankoi and Kalasira. Required amount of FYM and phosphatic fertilizers were well mixed with the soils of nursery for development of fertility of soil, before date of sowing. Seed treatment of above rice genotypes were done with the help of Carbendazim @ 3g/kg seed and Streptocycline @ 1.5g/kg seed followed by washing with distilled water. Seeds were soaked in this treated water for $24 \mathrm{hrs}$ and subsequently placed on moist gunny bags for sprouting. Sprouted seeds were direct seeded at $1 \mathrm{~cm}$ depth in the twenty two varieties were sown in lines with keeping appropriate spacing between the varieties. The irrigation channels were kept surrounding the speed beds. Frequent sprinkler irrigation was given for seed bed initially and after germination management was done in such a manner that the raised seed bed remained moistened without any standing water over its surface for one week. Thereafter standing water was maintained upto $3 \mathrm{cms}$. For the better growth of seedlings minimum $\mathrm{N}$-fertilizer was given in seed bed. Before 7 days of rooting of seedling granular pesticide was applied in seed bed @ $10 \mathrm{~kg} / \mathrm{ac}$ in order to avoid the infection of disease and pest after the transplanting. After 21 days of sowing the seedling was up rooted for transplanting. Natural flooding occurs at tillering stage of the rice for continuous 15 days. Data were taken just before and after the harvesting.

\section{Growth analytical parameters}

\section{Leaf Area Index (LAI)}

LAI is expressed as the ratio of leaf area (A) (only one side) to the ground area (P) occupied by the crop (Watson, 1947). 


\section{$\mathrm{LAI}=\mathrm{A} / \mathrm{P}$}

\section{Leaf Weight Ratio (LWR)}

LWR is expressed as the ratio of leaf dry weight (W0) to the total plant dry weight (W) (Gregory, 1926).

$\mathrm{LWR}=\mathrm{W} 0 / \mathrm{W}$

\section{Specific Leaf Area (SLA)}

SLA is the ratio between leaf areas (A) and

Leaf dry weight (WL) (Peacock, 1975)

$\mathrm{SLA}=\mathrm{A} / \mathrm{WL}$

\section{Specific Leaf Weight (SLW)}

SLW is the ratio between leaf dry weight (WL) and leaf area (A)

$\mathrm{SLW}=\mathrm{WL} / \mathrm{A}$

\section{Leaf Area Duration (LAD)}

LAD is defined as the leaf area index integrated over time $\mathrm{LAD}=\mathrm{A} 2-\mathrm{A} 1 / \mathrm{LnA} 2-$ LnA1 X (t2-t1).

Where

A1= Leaf Area Index at the start of test period

A2=Leaf Area Index at the end of test period

$\mathrm{t} 2$ - $\mathrm{t} 1=$ Period in days between initial and final observation

\section{Leaf area ratio (LAR)}

LAR is defined as the ratio between leaf area (A) and total plant dry weight (W)

$\mathrm{LAR}=\mathrm{A} / \mathrm{W}$

\section{Results and Discussion}

Growth analytical parameters of different rice varieties

The physiological characters of different rice varieties under test were influenced by submerged conditions during the growth periods. The following physiological parameters were revealed before and after submergence.

Leaf Area Index (LAI), Specific Leaf Area (SLA), Specific Leaf Weight (SLW)

The LAI vary widely among the cultivars under test after the submergence as compared to before, CR dhan-505 concluded highest LAI by 10.30 whereas minimum value (6.50) of the same was shown in Bankoi recorded at 75 days i.e. before the submergence when the crop was submerged for a period of 12 days completely, there was degeneration of tillers and the leaf area was reduced in all the varieties. It was found that there was reduced of leaf area due to submergence and the LAI was reduced. The percentage of reduction was minimum in Sabita $(15.19 \%)$ whereas the maximum reduction was occurred in Kalasira $(62.32 \%)$. After submergence there was regeneration of the varieties and the leaf area was increased so that LAI was increased. The maximum LAI was recorded by Sabita (6.70), whereas the minimum LAI was noted in Kalasira (2.60) (Table 1).

Rice verities differ in physiological age and activity for emergence of leaves. From the seedling stage rice plant takes 4-5 days for emergence a leaf and it is extended to 7-8 days before the panicle initiation (Yoshida, 1981). It was observed that the maximum LAI was obtained from a rice plant during its vegetative stage to a tune of $10-12$ but the critical LAI value for optimum photosynthesis is 67 under normal or optimum weather condition. It was 
revealed from the data that maximum LAI was observed 10.30 from CR dhan-505 followed by Jalamani (10.20) whereas the minimum value of the same was recorded from Bankoi (6.50) before the submergence.

Due to submergence there was damage of tillers as anoxia was created and irrespective of varieties there was reduction of tiller number. Among the varieties maximum LAI was recorded from Sabita (6.7) followed by FR-43B (6.2) and Jalamagna (5.8) whereas Kalasir showed the minimum value (2.60).

Among the varieties the maximum SLA was contributed by Bankoi $(393.82 \mathrm{~cm} 2 / \mathrm{g})$ whereas the minimum value was recorded from Sabita $(181.24 \mathrm{~cm} 2 / \mathrm{g})$. After the submergence irrespective of cultivars there was increase of SLA and the percentage of increase range from $5.99 \%$ in Jalamagna to $20.45 \%$ in OR-142/99.

The specific leaf weight (SLW) was higher in CR dhan-500 $(5.51 \mathrm{mg} / \mathrm{cm} 2)$ whereas the minimum value was exhibited by Kalasira $(2.53 \mathrm{mg} / \mathrm{cm} \mathrm{2})$. But after submergence there was reduction of SLW in all the cultivars and the highest value was recorded from Sabita $\left(4.30 \mathrm{mg} / \mathrm{cm}^{2}\right)$ with minimum value in Bankoi $\left(2.21 \mathrm{mg} / \mathrm{cm}^{2}\right)$.

Leaf area ratio (LAR), relative growth rate (RGR), leaf weight ratio (LWR)

The LAR was influenced by submerged condition as compared with before submergence. It was found that Maximum LAR $\left(80.08 \mathrm{~cm}^{2} / \mathrm{gm}\right)$ was recorded by Sabita followed by CR Dhan-505 $\left(71.60 \mathrm{~cm}^{2} / \mathrm{gm}\right)$ and followed by Jalamgna $\left(71.36 \mathrm{~cm}^{2} / \mathrm{gm}\right)$ where minimum value of the same was shown in OR-2331/14 $\left(34.81 \mathrm{~cm}^{2} / \mathrm{gm}\right)$ before the submergence. It was found that after submergence the tolerant variety FR-43 B exhibited maximum LAR $\left(63.79 \mathrm{~cm}^{2} / \mathrm{gm}\right)$ followed by Sabita $\left(58.68 \mathrm{~cm}^{2} / \mathrm{gm}\right)$ whereas minimum value was recorded from Bankoi $\left(26.99 \mathrm{~cm}^{2} / \mathrm{g}\right)$. Significant difference was found among the genotypes but not within the replication. LAR was highly positively correlated with grain yield, grains/panicle, shoot dry matter and harvest index (Table 2).

The RGR of the genotypes varied from 17.05 $\mathrm{mg} / \mathrm{g} /$ day to $21.88 \mathrm{mg} / \mathrm{g} /$ day before the submergence whereas RGR recorded from after the submergence to harvesting varied from $12.63 \mathrm{mg} / \mathrm{g} /$ day to $19.23 \mathrm{mg} / \mathrm{g} /$ day. The highest RGR during the peak vegetative stage was highest in Sabita $(21.88 \mathrm{mg} / \mathrm{g} /$ day $)$ followed by FR-43B ( $21.69 \mathrm{mg} / \mathrm{g} /$ day $)$.

The percentage of reduction of RGR due to submergence range from $12.11 \%$ to $24.52 \%$ as compared to the vegetative stage. Significant difference was noted among the treatments. There was highly positive correlation of RGR with grain yield, grains/panicle, shoot dry matter and negatively correlated with sterility percentage.

The weight ratio (LWR) recorded before and after submergence was reflected in Table 2. Comparison of LWR among the genotypes revealed that Bankoi had the highest LWR $(0.27)$ followed by Mayurakantha (0.24) whereas the minimum value of the same was exhibited by CR-1030 (0.13) before the submergence. Data recorded after the submergence revealed that highest LWR was shown by Bankoi (0.19) but CR dhan-500 and OR-2328/05 noted the lowest value (0.11).

The percentage of reduction of LWR range from $15.00 \%$ to $40.91 \%$ due to submergence as compared to before submergence. Significant difference was found among the replication and within the varieties. From the correlation Table 4 it was clear that LWR is highly correlated with the yield and yield attributing characters. 
Table.1 Variation in leaf area index (LAI), specific leaf area (SLA), specific leaf weight (SLW) in response to submerged condition in different rice cultivars

\begin{tabular}{|c|c|c|c|c|c|c|c|c|}
\hline \multirow{2}{*}{\multicolumn{2}{|c|}{ VARIETY }} & \multicolumn{3}{|l|}{ LAI } & \multicolumn{2}{|c|}{$\operatorname{SLA}(\mathrm{cm} 2 / \mathrm{g})$} & \multicolumn{2}{|r|}{ SLW (mg/cm2) } \\
\hline & & BS & & AS & BS & AS & BS & AS \\
\hline Sabita & & 7.90 & & $\begin{array}{l}6.70 \\
(-15.19 \%)\end{array}$ & 181.24 & $208.82(+15.22 \%)$ & 4.70 & $\begin{array}{l}4.30 \\
(-8.51 \%)\end{array}$ \\
\hline FR-43B & & 7.40 & & $\begin{array}{l}6.20 \\
(-16.22 \%)\end{array}$ & 212.38 & $267.56(+25.98 \%)$ & 3.97 & $\begin{array}{l}3.87 \\
(-2.52 \%)\end{array}$ \\
\hline Jalamgna & & 8.50 & & $\begin{array}{l}5.80 \\
(-31.76 \%)\end{array}$ & 243.78 & $258.38(+5.99 \%)$ & 4.07 & $\begin{array}{l}3.57 \\
(-12.29 \%)\end{array}$ \\
\hline OR-2331/14 & & 9.90 & & $\begin{array}{l}4.00 \\
(-59.60 \%)\end{array}$ & 245.69 & $271.15(+10.36 \%)$ & 4.10 & $\begin{array}{l}3.73 \\
(-9.02 \%)\end{array}$ \\
\hline IR 85085 SUB-17 & & 7.10 & & $\begin{array}{l}5.30 \\
(-25.35 \%)\end{array}$ & 248.41 & $267.34(+7.62 \%)$ & 4.02 & $\begin{array}{l}3.74 \\
(-6.97 \%)\end{array}$ \\
\hline JayantiDhana & & 8.90 & & $\begin{array}{l}5.30 \\
(-40.45 \%)\end{array}$ & 251.78 & $285.51(+13.40 \%)$ & 3.86 & $\begin{array}{l}3.68 \\
(-4.66 \%)\end{array}$ \\
\hline Jalamani & & 10.20 & & $\begin{array}{l}5.30 \\
(-48.04 \%)\end{array}$ & 257.14 & $288.66(+12.26 \%)$ & 3.88 & $\begin{array}{l}3.50 \\
(-9.79 \%)\end{array}$ \\
\hline CR dhan-500 & & 5.30 & & $\begin{array}{l}4.60 \\
(-15.22 \%)\end{array}$ & 258.48 & $290.1(+12.23 \%)$ & 5.51 & $\begin{array}{l}4.78 \\
(-13.25 \%)\end{array}$ \\
\hline CR dhan-401 & & 7.00 & & $\begin{array}{l}5.00 \\
(-28.57 \%)\end{array}$ & 258.95 & $291.93(+12.74 \%)$ & 3.87 & $\begin{array}{l}3.46 \\
(-10.59 \%)\end{array}$ \\
\hline CR dhan-505 & & 10.30 & & $4.90(52.43 \%)$ & 258.04 & $293.19(+13.62 \%)$ & 3.86 & $\begin{array}{l}3.44 \\
(-10.88 \%)\end{array}$ \\
\hline Mahalaxmi & & 6.90 & & $\begin{array}{l}4.70 \\
(-31.88 \%)\end{array}$ & 264.49 & $294.69(+11.42 \%)$ & 3.78 & $\begin{array}{l}3.42 \\
(-9.52 \%)\end{array}$ \\
\hline Manika & & 6.60 & & $\begin{array}{l}4.40 \\
(-33.33 \%)\end{array}$ & 264.89 & $297.36(+12.26 \%)$ & 3.77 & $\begin{array}{l}3.41 \\
(-9.55 \%)\end{array}$ \\
\hline CR dhan-1030 & & 6.60 & & $\begin{array}{l}4.30 \\
(-34.84 \%)\end{array}$ & 266.11 & $314.4(+18.15 \%)$ & 3.75 & $\begin{array}{l}3.36 \\
(-10.40 \%)\end{array}$ \\
\hline OR-142/99 & & 7.90 & & $\begin{array}{l}4.20 \\
(-46.84 \%)\end{array}$ & 275.92 & $332.34(+20.45 \%)$ & 3.62 & $\begin{array}{l}3.39 \\
(-6.35 \%)\end{array}$ \\
\hline Tanmayee & & 5.50 & & $\begin{array}{l}4.80 \\
(-12.17 \%)\end{array}$ & 289.93 & $327.14(+12.83 \%)$ & 3.49 & $\begin{array}{l}3.18 \\
(-8.88 \%)\end{array}$ \\
\hline Urbashi & & 6.70 & & $\begin{array}{l}3.90 \\
(-41.79 \%)\end{array}$ & 285.73 & $337.1(+17.98 \%)$ & 3.44 & $\begin{array}{l}3.05 \\
(-11.34 \%)\end{array}$ \\
\hline Salibahana & & 8.20 & & $\begin{array}{l}3.90 \\
(-52.44 \%)\end{array}$ & 295.3 & $342.1(+15.85 \%)$ & 3.38 & $\begin{array}{l}2.96 \\
(-12.43 \%)\end{array}$ \\
\hline Rambha & & 7.40 & & $\begin{array}{l}3.80 \\
(-48.65 \%)\end{array}$ & 304.59 & $359.85(+18.14 \%)$ & 3.28 & $\begin{array}{l}2.87 \\
(-12.50 \%)\end{array}$ \\
\hline OR/2328/05 & & 7.00 & & $\begin{array}{l}3.60 \\
(-48.57 \%)\end{array}$ & 321.88 & $383.49(+19.14 \%)$ & 3.10 & $\begin{array}{l}2.66 \\
(-14.19 \%)\end{array}$ \\
\hline Mayurakantha & & 7.40 & & $\begin{array}{l}2.90 \\
(-60.81 \%)\end{array}$ & 342.44 & $425.2(+24.17 \%)$ & 2.92 & $\begin{array}{l}2.77 \\
(-5.14 \%)\end{array}$ \\
\hline Kalasira & & 6.90 & & $\begin{array}{l}2.60 \\
(-62.32 \%)\end{array}$ & 375.68 & $400.24(+6.54 \%)$ & 2.53 & $\begin{array}{l}2.49 \\
(-1.58 \%)\end{array}$ \\
\hline Bankoi & & 6.50 & & $\begin{array}{l}4.00 \\
(-38.46 \%)\end{array}$ & 393.82 & $451.96(+14.76 \%)$ & 2.66 & $\begin{array}{l}2.21 \\
(-16.92 \%)\end{array}$ \\
\hline SEM & & & 0.17 & $\begin{array}{ll}02 & 0.03\end{array}$ & 0.04 & 0.03 & & \\
\hline C.D 5\% & 0.45 & 0.48 & 0.06 & $\begin{array}{ll}0.08 & 0.10\end{array}$ & 0.08 & & & \\
\hline C.V & 3.66 & 6.24 & 0.01 & $\begin{array}{ll}0.02 & 1.67\end{array}$ & 1.45 & & & \\
\hline
\end{tabular}


Table.2 Variation in leaf area ratio (LAR), relative growth rate (RGR), leaf weight ratio (LWR) in different rice cultivars

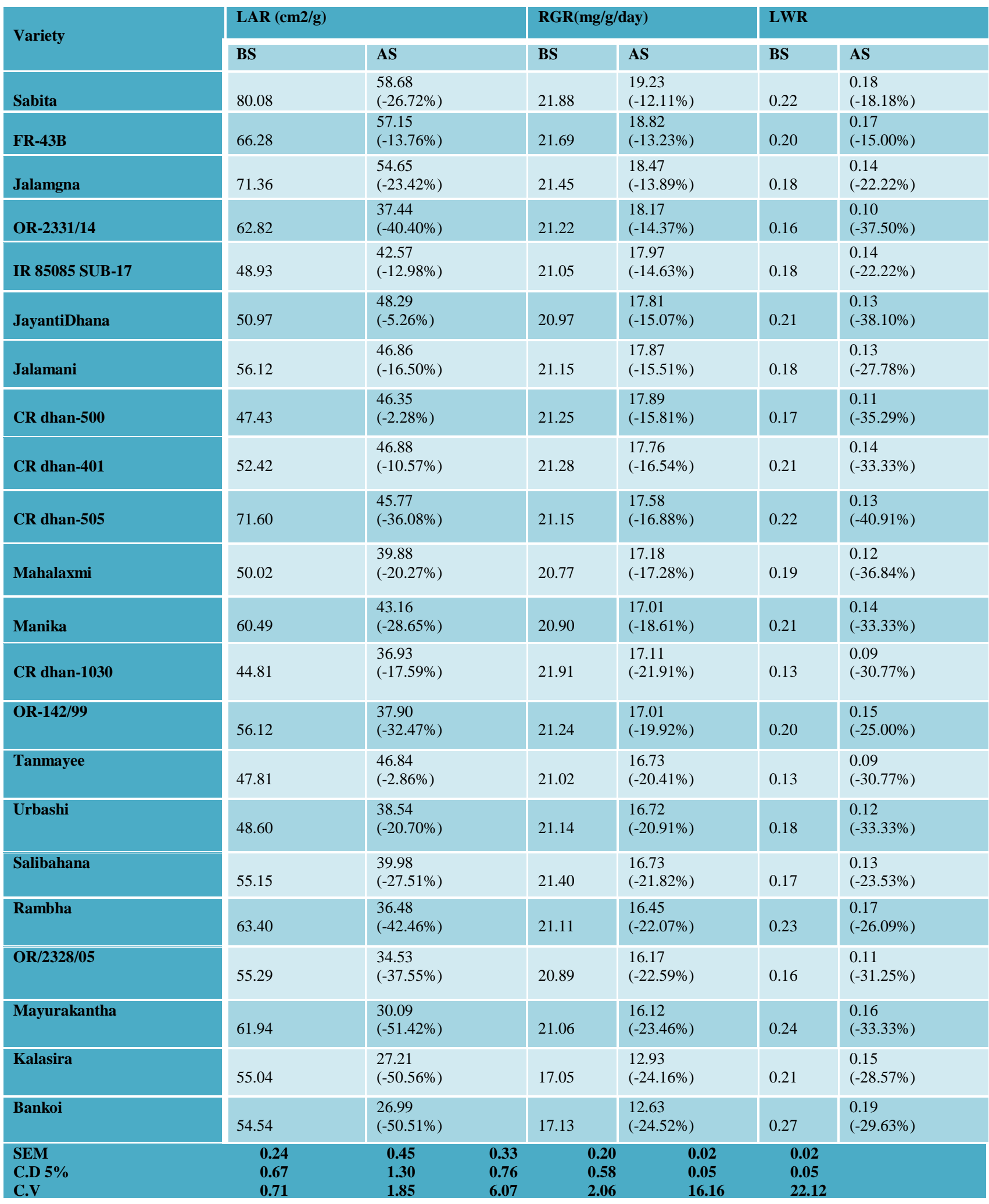


Table.3 Variation in crop growth rate (CGR), net assimilation rate (NAR) \& leaf area duration (LAD) in response to submerged condition in different rice cultivars

\begin{tabular}{|c|c|c|c|c|c|}
\hline \multirow[t]{2}{*}{ SI. No. } & \multirow[t]{2}{*}{ Variety } & \multicolumn{2}{|c|}{ CGR (mg/m2/day) } & \multirow{2}{*}{$\begin{array}{l}\text { NAR }\left(\mathrm{mg} / \mathrm{dm}^{2} / \text { day }\right) \\
\text { AS }\end{array}$} & \multirow[t]{2}{*}{ LAD (days) } \\
\hline & & BS & $\mathbf{A S}$ & & \\
\hline 1 & Sabita & 33.42 & $\begin{array}{l}18.28 \\
(-45.30 \%)\end{array}$ & 38.15 & 141.20 \\
\hline 2 & FR-43B & 28.50 & $\begin{array}{l}11.96 \\
(-58.04 \%)\end{array}$ & 34.08 & 136.72 \\
\hline 3 & Jalamgna & 35.33 & $\begin{array}{l}17.03 \\
(-51.80 \%)\end{array}$ & 29.82 & 134.55 \\
\hline 4 & OR-2331/14 & 27.95 & $\begin{array}{l}15.77 \\
(-43.58 \%)\end{array}$ & 26.73 & 130.34 \\
\hline 5 & IR 85085 SUB-17 & 27.91 & $\begin{array}{l}14.34 \\
(-48.62 \% 0\end{array}$ & 27.54 & 128.43 \\
\hline 6 & JayantiDhana & 25.59 & $\begin{array}{l}12.53 \\
(-51.04 \%)\end{array}$ & 24.15 & 130.92 \\
\hline 7 & Jalamani & 32.62 & $\begin{array}{l}12.29 \\
(-62.32 \%)\end{array}$ & 26.47 & 128.35 \\
\hline 8 & CR dhan-500 & 26.97 & $\begin{array}{l}11.94 \\
(-55.73 \%)\end{array}$ & 21.43 & 129.00 \\
\hline 9 & CR dhan-401 & 24.02 & $\begin{array}{l}11.41 \\
(-52.50 \%)\end{array}$ & 21.65 & 126.21 \\
\hline 10 & CR dhan-505 & 20.77 & $\begin{array}{l}10.88 \\
(-47.62 \%)\end{array}$ & 21.53 & 126.72 \\
\hline 11 & Mahalaxmi & 20.57 & $\begin{array}{l}10.38 \\
(-49.54 \%)\end{array}$ & 21.36 & 127.43 \\
\hline 12 & Manika & 21.13 & $\begin{array}{l}10.07 \\
(-52.34 \%)\end{array}$ & 28.83 & 129.42 \\
\hline 13 & CR dhan-1030 & 20.44 & $\begin{array}{l}9.68 \\
(-52.64 \%)\end{array}$ & 22.19 & 126.32 \\
\hline 14 & OR-142/99 & 16.53 & $\begin{array}{l}8.45 \\
(-48.88 \%)\end{array}$ & 18.50 & 125.23 \\
\hline 15 & Tanmayee & 15.46 & $\begin{array}{l}7.96 \\
(-48.51 \%)\end{array}$ & 23.20 & 124.77 \\
\hline 16 & Urbashi & 14.00 & $\begin{array}{l}7.67 \\
(-45.21 \%)\end{array}$ & 21.75 & 123.63 \\
\hline 17 & Salibahana & 18.98 & $\begin{array}{l}7.28 \\
(-61.64 \%)\end{array}$ & 20.96 & 121.73 \\
\hline 18 & Rambha & 10.53 & $\begin{array}{l}7.12 \\
(-32.38 \%)\end{array}$ & 18.57 & 119.82 \\
\hline 19 & OR/2328/05 & 25.22 & $\begin{array}{l}6.55 \\
(-74.03 \%)\end{array}$ & 19.66 & 116.30 \\
\hline 20 & Mayurakantha & 29.06 & $\begin{array}{l}6.17 \\
(-78.77 \%)\end{array}$ & 20.22 & 115.62 \\
\hline 21 & Kalasira & 16.47 & $\begin{array}{l}5.88 \\
(-64.30 \%)\end{array}$ & 18.88 & 120.23 \\
\hline 22 & Bankoi & 19.08 & $\begin{array}{l}5.72 \\
(-70.02 \%)\end{array}$ & 17.36 & 119.41 \\
\hline & SEM & 0.03 & 1.28 & 0.02 & 0.03 \\
\hline & C.D 5\% & 0.08 & 3.64 & 0.06 & 0.08 \\
\hline & C.V & 0.22 & 21.21 & 0.16 & 0.04 \\
\hline
\end{tabular}


Table.4 Correlation coefficient relation matrix between crop yield and its attributing characters and physiological parameters of rice cultivars

\begin{tabular}{|c|c|c|c|c|c|c|c|}
\hline & $\begin{array}{c}\text { Grain } \\
\text { yield/ha }\end{array}$ & $\begin{array}{c}\text { Grains/ } \\
\text { panicle }\end{array}$ & $\begin{array}{c}\text { 1000 grain } \\
\text { weight }\end{array}$ & $\begin{array}{c}\text { Shoot } \\
\text { DM/m2 } \\
\text { (harvest) }\end{array}$ & $\begin{array}{c}\text { Panicle } \\
\text { length }\end{array}$ & $\begin{array}{c}\text { Survival } \\
\text { Percentage }\end{array}$ & $\begin{array}{c}\text { Sterility } \\
\text { Percentage }\end{array}$ \\
\hline $\begin{array}{c}\text { Grain } \\
\text { yield/ha }\end{array}$ & & 0.811 & 0.232 & 0.920 & 0.742 & 0.996 & 0.846 \\
\hline LAI & 0.849 & 0.249 & 0.277 & 0.737 & 0.870 & 0.845 & 0.832 \\
\hline SLA & -0.970 & -0.091 & -0.024 & -0.875 & -0.801 & -0.961 & -0.875 \\
\hline SLW & -0.842 & 0.111 & 0.108 & 0.759 & 0.263 & 0.862 & -0.789 \\
\hline LWR & -0.187 & 0.229 & 0.246 & 0.369 & 0.110 & -0.183 & 0.045 \\
\hline LAR & 0.873 & 0.734 & 0.233 & 0.753 & 0.422 & 0.876 & 0.838 \\
\hline RGR & 0.725 & 0.720 & 0.101 & 0.483 & 0.242 & 0.720 & 0.910 \\
\hline NAR & 0.744 & 0.701 & 0.027 & 0.521 & 0.350 & 0.744 & 0.889 \\
\hline CGR & 0.866 & 0.812 & 0.039 & 0.679 & 0.228 & 0.848 & 0.912 \\
\hline LAD & 0.822 & 0.819 & 0.139 & 0.695 & 0.546 & 0.883 & 0.948 \\
\hline
\end{tabular}

Crop Growth Rate (CGR), Net Assimilation Rate (NAR), Leaf Area Duration (LAD)

Among the cultivars highest CGR was obtained from Jalamgna $\left(35.33 \mathrm{mg} / \mathrm{m}^{2} /\right.$ day) followed by Sabita $\left(33.42 \mathrm{mg} / \mathrm{m}^{2} /\right.$ day $)$ while the lowest value was exhibited from Rambha $\left(10.53 \mathrm{mg} / \mathrm{m}^{2} /\right.$ day) before the submergence. There was reduction of CGR due to submergence irrespective of genotypes. The percentage of reduction was range from $43.58 \%$ to $78.77 \%$. Highest CGR was obtained from Sabita $\left(18.28 \mathrm{mg} / \mathrm{m}^{2} /\right.$ day) whereas the minimum CGR was recorded from Bankoi $\left(5.34 \mathrm{mg} / \mathrm{m}^{2} /\right.$ day). There was significant difference among the varieties as well as within the replication. There was highly positive correlation between CGR with yield and yield attributing characters but negatively correlated with sterility percentage (Table 4).

Comparison between the varieties as regards to NAR activity which was revealed from the data presented in Table 3 that Sabita exhibit the maximum value $\left(38.15 \mathrm{mg} / \mathrm{dm}^{2} /\right.$ day $)$ followed by FR-43B ( $34.08 \mathrm{mg} / \mathrm{dm}^{2} /$ day) but the minimum value was recorded from Bankoi (17.36 mg/dm²/day). As per the C.V. value there was variation among the cultivars in NAR activities. Data presented in Table 4 indicated that there was highly positive correlation between NAR with yield and yield attributing characters with grain yield, grains/panicle and shoot dry matter but poorly correlated with percentage of ripened grains and sterility percentage.

Variation in Leaf Area Duration (LAD) among the cultivars estimated from heading to maturity revealed that maximum LAD was recorded from Sabita (141.20 days) followed by FR-43B (136.72days) but the minimum value of the same was recorded in Mayurakantha (115.62 days) which was $18.11 \%$ less from the highest value. Significant difference among the cultivars is found (Table 3).

Specific Leaf Weight (SLW) and Leaf Area Ratio decreased due to submergence. NAR is positively associated with SLW and negatively with LAR. So SLW can be 
selected as a useful parameter for selection of a variety to have higher NAR at vegetative stress under stress prone environment (Chaddha and Khan, 1999).

The Leaf Area Duration (LAD) measured from the flowering to harvest was found highest in Sabita (141.2 Days) followed by FR-43B (135.7 Days). LAD expresses the persistence of leaf area or leafiness during the period of crop growth by which interception of light will be better. It is highly correlated with yield (Gardner et al., 1985).

\section{Correlation coefficient relation matrix between crop yield and its attributing characters and growth analytical parameters}

There is a positive correlation between LAI with grain yield $(\mathrm{r}=0.849)$ and negative correlation with SLA ( $\mathrm{r}=-0.970)$. Among the varieties the maximum SLA was contributed by Bankoi $\left(393.82 \mathrm{~cm}^{2} / \mathrm{g}\right)$ whereas the minimum value was recorded from Sabita $(181.24 \mathrm{~cm} 2 / \mathrm{g})$. SLW is negatively correlated with grain yield $(r=-0.842)$ and shoot dry matter. There was positive correlation between the LAR with grain yield $(r=0.873)$ and number of filled up grains $(r=0.734)$ but negatively correlated with sterility percentage $(\mathrm{r}=-0.838)$. The Relative Growth Rate (RGR) has a positive correlation with grain yield $(r=0.725)$ and its attributing characters like shoot dry matter at maturity $(\mathrm{r}=0.483)$, panicle length $(\mathrm{r}=0.242)$ and survival percentage $(r=0.720)$ but negatively correlated with the sterility percentage $(\mathrm{r}=$ 0.910). SLW is negatively correlated with grain yield $(r=-0.842)$ and shoot dry matter.

The Crop Growth Rate (CGR) was positively correlated with grain yield $(\mathrm{r}=0.866)$ and survival percentage ( $\mathrm{r}=0.848$ ) but negatively correlated with sterility percentage $(r=$ 0.912). The Net Assimilation Rate (NAR) was a positive correlation between the NAR and grain yield $(\mathrm{r}=0.744)$ but negatively correlated with sterility percentage $(\mathrm{r}=-0.899)$ (Table 4).

Leaf area duration (LAD) estimated from flowering to maturity indicated that the highest value was exhibited by Sabita (141.20 days) followed by FR-43B (136.70 days) (Table 4). LAD has positive correlation with grain yield $(\mathrm{r}=0.822)$ and survival percentage $(\mathrm{r}=0.883)$ but negatively correlated with sterility percentage $(\mathrm{r}=$ 0.948) (Table 4).

From the above growth analysis we validated that the cultivar Sabita is appears to be the best choice for periodic water stress condition. The cultivar FR-43B was the next best after Sabita for cultivation in such condition. The physiological attributes of these two cultivars may be used for breeding a cultivar for a particular environment.

\section{Acknowledgment}

The precious piece of acknowledgement provides me an esteemed opportunity to express my profound sense of gratitude and indebtedness to The Department of Plant Physiology, College of Agriculture, OUAT, Bhubaneswar for the financial and technical support.

\section{References}

Bhowmick, M. K., Dhara, M. C., Singh, S., Dar, M. H., and Singh, U. S. 2014. Improved management options for submergence-tolerant (Sub1) rice genotype in flood-prone rainfed lowlands of West Bengal. American Journal of Plant Sciences, 5:14-23.

Chaddha, T.M., and Khan, M.A. 1991. Study on relationship between physiological parameters of indices. 
Pakistan Journal of Scientific and Industrial Research, 34(1): 37-39

Dar, M.H., Janvry, A.D., Emerick, K., Raitzer, D., and Sadoulet, E. 2013. Flood tolerant rice reduces yield variability and raises expected yield, differentially benefitting socially disadvantaged groups. Scientific Reports, 3:1-8.

Dawe, D., Pandey, S., and Nelson A. 2010. "Emerging trends and spatial patterns of rice production," in Rice in the Global Economy: Strategic Research and Policy Issues for Food Security, eds S. Pandey, D. Byerlee, D. Dawe, A. Dobermann, S. Mohanty, S. Rozelle, and B. Hardy (Los Banos: International Rice Research Institute), 15-35

Gardner, F.P., Pearce, R.B., and Mitchell, R.L. 1985. Physiology of Crop Plants. 2nd Edn., Iowa State University Press, Ames, IA., USA.

Septiningsih, E.M., Pamplona, A.M., Sanchez, D.L., Neeraja, C.N., Vergara, G.V., Heuer, S., Ismail, A.M., and Mackill, D.J. 2009. Development of submergence-tolerant rice cultivars: the Sub1 locus and beyond. Annals of Botany, 103: 151-160.

Yoshida S. 1981. Fundamental of Crop science. Intl. Rice Res. Institute, Los Banos, Leguna, Phillipines, pp. 269

Zain, N.A.M., Ismail, M.R., Puteh, A., Mahmood, M., and Islam, M.R. 2014. Impact of cyclic water stress on growth, physiological responses and yield of rice (Oryza sativa L.) grown in tropical environment. Cienc Rural. 44: 21362141.

\section{How to cite this article:}

Neeva Mohapatra and Hota, B.K. 2018. Impact of Submergence Stress on Growth analytical Parameters of Different Rice Genotypes in Coastal Odisha. Int.J.Curr.Microbiol.App.Sci. 7(10): 973-982. doi: https://doi.org/10.20546/ijcmas.2018.710.108 